\title{
Parcursul diacronic al formelor de viitor din limba franceză din prisma teoriei regramatizării
}

\author{
Cecilia-Mihaela Popescu* \\ Facultatea de Litere, Universitatea din Craiova, Str. Alexandru Ioan Cuza 13, 200585 Craiova, România
}

Despre articol
Istoric:
Primit 26 ianuarie 2018
Acceptat 13 februarie 2018
Publicat 27 aprilie 2018
Cuvinte-cheie:
gramaticalizare
regramatizare
viitor sintetic
forma în -rai
structuri prospective perifrastice
epistemic probabil

Despre articol

Primit 26 ianuarie 2018

Acceptat 13 februarie 2018

Cuvinte-cheie:

gramaticalizare

regramatizare

viitor sintetic

structuri prospective perifrastice epistemic probabil

\begin{abstract}
Rezumat
Derivat dintr-un amplu studiu postdoctoral, articolul de față își propune să prezinte evoluția formelor de viitor din limba franceză din prisma acțiunii procesului de regramatizare, înțeles ca reorganizare a sistemului gramatical al unei limbi (v. Andersen, 2006; Lindschouw, 2011). În linii foarte generale, acest proces poate fi descris astfel: structura canonică de viitor, care reprezintă inițial rezultatul unui proces anterior de gramaticalizare (în sensul de trecere de la lexical la gramatical), ajunge cu timpul să aibă un comportament morfosintactic și semantic polifuncțional, actualizînd mai mult de o valoare gramaticală. $\mathrm{O}$ astfel de situație va antrena selectarea unor noi constituenți în cadrul paradigmei canonice de viitor şi va determina în mod inevitabil: (i) concurența dintre forma inițială și cele nou create; (ii) desemantizarea și specializarea pe un anumit segment informațional a formei canonice, respectiv (iii) gramaticalizarea (totală sau parțială) formelor perifrastice concurente. Vom vedea astfel că forma sintetică de viitor din limba franceză a suferit o diminuare semantico-funcțională în zona actualizării [prospectivului] temporal, această situație datorîndu-se în mare măsură „intervenției” și gramaticalizării pe aceeaşi zonă conceptuală a perifrazei itive aller + infinitiv, care, în limba actuală vorbită, a devenit principala formă de exprimare a [viitorului]. Un grad și mai mare de diminuare a numărului de ocurențe se observă și în zona utilizărilor modale pure, în limba vorbită, locutorii nativi manifestînd preferința tot pentru o tunură perifrastică, și anume devoir epistemic + infinitiv.
\end{abstract}

\section{Introducere}

\subsection{Gramaticalizare și regramatizare}

Orice sistem lingvistic suferă în permanență modificări, iar paradigmele verbale de viitor (siglat în text: V) din limbile romanice au suferit și ele diverse schimbări semantico-sintactice din momentul fixării lor în limbă şi pînă în contemporaneitate, antrenînd uneori chiar reorganizări de paradigmă sau conducînd la crearea unor noi tipuri de opoziții la nivel de sistem.

Această transformare continuă care afectează anumite forme care au obținut deja un statut gramatical la nivelul sistemului readuce în discuție problematica gramaticalizării sau, cel puțin, maniera tradițională de conceptualizare a acestui fenomen lingvistic (v. Meillet, 1912, p. 130-148 sau Lehmann, 1985, p. 303318).

Gramaticalizarea văzută în canonul clasic desemnează procesul de trecere de la lexical la gramatical, altfel spus, procesul prin care un item independent din punct de vedere semantico-lexical şi sintactic își pierde progresiv semnificația originară. Prin funcționarea frecventă în anumite tipare sintactice, din ce în ce mai puțin variate, acest lexem ajunge să devină dependent sintactic. Absența unei semnificații lexicale proprii, comportamentul funcțional dependent, coroborat cu eroziunea formală, tot acest şir de procese ireversibile (deci, cu sens unidirecțional) conduc itemul lexical originar la statutul de morfem gramatical.

\footnotetext{
*Adresă de corespondență: cecilia99_ro@yahoo.com.
} 
Studii recente (v. Andersen, 2001; 2006, p. 231-258 sau Lindschouw, 2011, p. 57-63; 2013, p. $93-$ 95) au arătat faptul că sub umbrela extrem de generoasă a gramaticalizării intră o serie întreagă de procese lingvistice, precum regramaticalizarea, regramatizarea sau reanalizarea, care au fost recent definite și dezambiguizate. De exemplu, Andersen (2006, p. 231-258) consideră procesul de gramaticalizare ca fiind format dintr-o serie de alte procese secundare, pe care le numește gramatizări <grammation(s)> și regramatizări <régrammation $(s)>$. Prin gramatizare, autorul danez înțelege „[...] un changement de contenu, au moyen duquel une catégorie qui n'a pas un contenu grammatical l'obtient" (Lindschouw, 2011, p. 59), în timp ce o regramatizare reprezintă o reorganizare a unui conținut gramatico-funcțional în interiorul unui sistem gramatical, sau, în termenii propuşi de Lindschouw (2011, p. 60), ,une réorganisation à l'intérieur d'un paradigme clos [s.n.] qui présuppose un changement de la relation entre la forme et le contenu accompagné d'au moins une réduction paradigmatique”.

Distincția dintre gramaticalizare și regramatizare apare clar ilustrată în interiorul paradigmei de V din limba franceză contemporană, unde forma analitică de V (aller chanter) se găsește acum în plin proces de gramaticalizare, în timp ce forma sintetică (chanterai) „est grammaticalisée depuis des temps immémoriaux" (Lindschouw, 2011, p. 57, nota 4). Însă, potrivit accepțiunii lărgite acordate recent procesului de gramaticalizare (înțeles acum in extenso ca reorganizare a sistemelor gramaticale), forma sintetică de V din limba franceză contemporană este cea care se găsește în plin proces de gramaticalizare (sau, mai precis, de regramatizare), „[...] dans la mesure où son domaine d'emploi se restreint à l'intérieur du système du futur, alors que le futur analytique ouvre le sien" (Lindschouw, 2011, p. 57, nota 4).

De altfel, în studiul său dedicat evoluției sistemului V din limba franceză, Lindschouw (2011, p. 60_ 63) sintetizează și posibilele etape pe care le poate traversa un proces de regramatizare, și anume:

- reducția paradigmatică sau paradigmaticitatea (v. și Lehmann, 1985), care se referă la anularea opozițiilor stabilite între constituenții unei paradigme. Acest proces rezultă în urma diminuării treptate a posibilității de alternare a respectivilor itemi și conduce la obligativitatea și specializarea lor în plan sintagmatic;

- desemantizarea conținutului semantico-funcțional al paradigmei în cauză;

- reanalizarea, o strategie de comprehensiune din partea locutorului, cu caracter cognitiv abstract care precede, de obicei, procesul de gramaticalizare sau pe cel de regramatizare și care acționează în primul rînd la nivelul conținutului și, ulterior, la nivel de structură morfosintactică.

Toate aceste etape care descriu procesul de regramatizare sau de gramaticalizare in extenso, pot fi astfel sintetizate:

„[... ] une forme A qui subira ultérieurement un processus de grammaticalisation, ou de régrammation dans notre cas, existe dans la langue pour traduire une valeur déterminée. Ensuite, une nouvelle forme $\mathrm{B}$, concurrente de $\mathrm{A}$, entre dans la langue, ce qui crée une ambiguïté référentielle [s.n.] entre la forme A et B. Enfin, la forme A se perd (ou souvent se (ré)grammaticalise), et seule la forme B est capable d'exprimer la valeur réservée autrefois à la forme A" (Lindschouw, 2011, p. 63).

\subsection{Regramatizarea viitorului sintetic din limba francez $\breve{a}$ - preliminarii}

În cele ce urmează, vom încerca să urmărim procesul de regramatizare a V sintetic din limba franceză. Așa cum am arătat mai sus, acest proces s-a realizat (sau continuă să se realizeze) în raport cu alți constituenți ai paradigmei de $V$, în mare parte, structuri perifrastice, analitice, mai mult sau mai puţin gramaticalizate. În linii foarte generale, el poate fi descris astfel: formele sintetice de $V$ reprezintă iniţial rezultate ale unor procese anterioare de gramaticalizare (de trecere de la lexical la gramatical) și, în mai mică măsură, chiar de regramatizare, atîta vreme cît formele preromanice (i.e., formele derivate din structura CANTARE HABEO) achiziționaseră deja un anumit statut funcțional în interiorul sistemului gramatical originar (latin, în cazul de față). Acești itemi gramaticali ajung cu timpul să aibă un comportament morfosintactic și semantic 
polifuncțional, actualizînd mai mult de o valoare gramaticală, fapt care va antrena selectarea unor noi constituenți în cadrul paradigmei de V din limba franceză. Această situație va determina în mod inevitabil:

(i) concurența dintre forma canonică de $\mathrm{V}$ și cele nou create;

(ii) desemantizarea și specializarea pe un anumit segment informațional a formei canonice și

(iii) gramaticalizarea (totală sau parțială) a formelor perifrastice.

Chiar dacă nu abordează evoluția formelor de V romanic din perspectiva extinsă a gramaticalizării, diferitele studii realizate în literatura de specialitate în cadru tipologic (v. Fleischman, 1982; Bybee et al., 1994; Barcelo, 2007, p. 47-62) avansează ideea unei evoluții ciclice pe care o înregistrează, în general, constituenții paradigmei în discuție, evoluție care traduce, în fapt, trecerea de la TEMPORALITATE la modalitate. De fapt, se poate configura chiar un anumit tipar de evoluție a morfemelor verbale care actualizază [ulterioritatea în raport cu $\mathrm{T}_{0}$ ], și acesta este bine sintetizat în definiția de mai jos:

„[...] o construcție, la origine modală, asociază la un moment dat mai mult de o valență temporală - [posterioritatea față de $\left.t_{0}\right]$, care, ulterior, devine trăsătura sa definitorie. După ce începe să fie utilizată exclusiv cu valoare de viitor, o astfel de construcție începe să dezvolte anumite semnificații modale, care, la rîndul lor, pot să se impună în detrimentul valorii temporale” (Corcheș \& Roman, 2011, p. 313).

\section{Viitorul sintetic din limba franceză și concurența sa cu diferite structuri peri- frastice}

În această secțiune, vom vedea - urmînd îndeaproape studiul propus de Lindschouw (2011, p. 51-63)— că forma sintetică de V din limba franceză a pierdut o mare parte din semnificațiile specifice actualizării referinței prospective, această situație datorîndu-se în mare măsură „intervenției” și gramaticalizării pe aceeași zonă conceptuală a perifrazei itive aller + infinitiv.

Înainte însă de a prezenta acest parcurs, se impun două observații cu caracter general:

(i) Gramaticalizarea unor turnuri construite la origine cu verbe de mişcare, de tipul: aller, venir etc. nu este un fenomen specific limbii franceze, ci se înregistrează și în alte zone ale Romaniei, în spaniolă, portugheză, catalană și, oarecum, și în italiană ${ }^{1}$. Studii de tipologie lingvistică (v., printre alții, Bybee et al., 1994) au analizat amănunțit evoluția acestor lexeme verbale cu semnificația originară [+mişcare] spre morfeme temporale (i.e., verbe auxiliare), prin asocierea cu un infinitiv sau cu un gerunziu, mai rar, cu un participiu trecut.

(ii) Diminuarea semantico-funcțională suferită de forma sintetică de V în zona actualizării [prospectivului] temporal a determinat o serie de lingviști (v. Harris, 1978; Bybee et al., 1994; Fleischman, 1982) să considere că în stadiul actual al limbii franceze, acest morfem verbal funcționează preponderent în zona modală și mai puțin în cea temporală. Însă, pe de o parte, analiza sincronică pe care noi am întreprins-o în diverse lucrări (v. Popescu, 2013, 2016) asupra valorilor pe care V le are în limba franceză contemporană și, pe de altă parte, studiul-anchetă propus de Wales (2007, p. 1-14) asupra dinamicii și frecvenței diferitelor tipuri de ocurențe ale acestei paradigme în limba vorbită, demonstrează că: în urma procesului de regramatizare, forma canonică de $V$ din limba franceză nu iese complet din uz, ci, dimpotrivă, continuă să își păstreze cea mai mare parte a utilizărilor încă ancorate în zona de expresie a [temporalului]. Mai mult chiar, în codul oral al acestui sistem lingvistic, $V$ sintetic apare foarte rar utilizat cu valori modale, acestea fiind, de fapt, sau temporalo-modale sau atenuative și, foarte rar, epistemice, zonă în care $\mathrm{V}$ este înlocuit frecvent de perifraza modală devoir ${ }_{\text {epistemic }}$

\footnotetext{
${ }^{1}$ În franceză, spaniolă și portugheză, V sintetic cu valoare pur temporală este concurat de anumite structuri perifrastice formate cu auxiliarul verbului „a merge” la indicativ prezent, urmat de infinitivul verbului lexical: (fr.) aller + infinitiv; (sp.) ir $+a+$ infinitiv; (port.) ir + infinitiv. În italiană, o structură echivalentă cu cele menționate anterior este andare $a+$ infinitiv, dar și forma progresivă, non-itivă, stare per + infinitiv.
} 
+ infinitiv sau cu indicativul prezent însoțit de adverbele modalizatoare probablement, sans doute, peut-être. În concluzie, ceea ce ni se pare important de reținut pentru demersul nostru este faptul că în franceză, forma canonică de $\mathrm{V}$ continuă să funcționeze frecvent în ocurențe temporale, că a pierdut—e adevărat—un mare număr dintre acestea (situație vizibilă mai cu seamă în codul oral) ca urmare a concurenței cu structura perifrastică aller + infinitiv, care, în limba actuală vorbită, a devenit principala formă de exprimare a [viitorului]. Însă, de fapt, cea mai semnificativă pierdere suferită de forma sintetică de V trebuie semnalată la nivelul utilizărilor modale, unde, de asemenea,

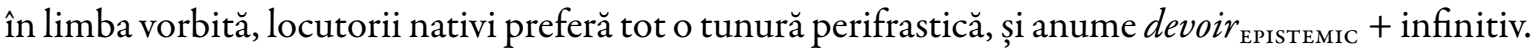

Vom vedea aşadar în continuare-pe scurt-cum s-a realizat acest diachronic change, pe care noi îl considerăm un proces de regramatizare (încă neîncheiat), pentru că antrenează diferite modificări semanticofuncționale și, astfel, o reorganizare a paradigmei de V din această limbă.

\subsection{Forma în -rai vs. perifraza itivă aller + infinitiv}

Predecesorul formei în - rai din franceza modernă apare atestat (ca formă deja sudată) chiar în primul text scris în această limbă, și anume: Les Serments de Strasbourg (anul 842 e.n.). În această perioadă, ca unică formă a paradigmei de V, morfemul verbal în discuție, descris de Moignet (1959, p. 289) ca „un futur comportant une dose d'hypothèse, si petite qu'on la fasse [...]", apare utilizat frecvent cu valoare temporală [ca de ex. infra sub (1a,b) sau sub (6)], dar și cu diferite nuanțe temporalo-modale, ca substitut al formei în -roie în redarea unei afirmații atenuate (2) și foarte rar cu valoare modală epistemică [astfel de cazuri întîlnindu-se în structuri interogativo-exclamative care contribuie la declanșarea unei puternice nuanțe modale a întregului enunț—de tipul, exprimare a unei deliberări asupra unei [probabilități], cu raportare la [prezent-viitor] — v. infra ex. (3)]:

(1) a. Ilz mangeront maint bon morseau // Les enffans, quant je seray vieuls (Villon, Le lais Villon et les poèmes variés, 23, 2160, apud Lindschouw, 2011, p. 74) [V sintetic cu valoare temporală, detaşată de [prezentul] lui $\mathrm{Sit}_{0}$ ].

b. A present je ne parleray principalment que du tiers mirouer de humaine creature, et de la belle ymaige de la benoite Trinité (Gerson, Sermon pour la fête de la sainte trinité, 155, 2057, anul 1402, apud Lindschouw, 2011, p. 74) [V sintetic cu valoare temporală, raportat la $\mathrm{Sit}_{0}$ ].

(2) C'iert granz damages, sil est deserites (Cor. Lo., 1410, apud Moignet, 1976, p. 289) [V sintetic cu valoare atenuativă în apodoza unui sistem condițional].

«Ce serait un grand domage, si...».

(3) a. Ferai le pendre ou se l'ardrai ? (Thèbes 8208, apud Moignet, 1976, p. 289)

b. Menderai li? -Tes, fous, ne feire... (Eneas 9073, apud Moignet, 1976, p. 289).

c. Deux! Que ferai? Por coi viv tant? (Erec 4617, apud Moignet, 1976, p. 289) [V sintetic în structuri interogative, cu nuanță dubitativă, exprimînd un <potențial probabil > cu raportare la [prezent-viitor]].

Altfel spus, în Ancien și Moyen Français, predecesorul formei în -rai exprimă [prospectivul] atît în raport cu $\mathrm{T}_{0}$ (deci funcționează deictic), cît și independent de acest parametru enunțiativ. Trebuie precizat că, în primul caz, distanța dintre localizarea evenimentului situat în [viitor] și momentul situației de comunicare nu este, în epoca studiată, o trăsătură relevantă în organizarea mijloacelor de expresie a [prospectivului]:

„Il est fort probable que pour un locuteur du moyen français, le futur synthétique exprimait une postériorité par rapport au moment de l'énonciation, peu importe la distance temporelle entre le moment de l'énonciation et le moment de l'événement exprimé par le verbe" (Lindschouw, 2011, p. 74).

Forma perifrastică de V apare în texte începînd cu secolul al XIV-lea, fiind construită deci dintr-un verb de mișcare și infinitivul unui verb lexical. Se crede că acele contexte care au favorizat gramaticalizarea acestei 
perifraze itive ca morfem temporal au fost cele în care era actualizat scopul mişcării, contexte reanalizate apoi de interlocutori în favoarea unei interpretări temporale. Trebuie precizat că aller + infinitiv nu este singura perifrază care apare în zona de expresie a [prospectivului] în epoca veche a limbii franceze. De fapt, spre deosebire de limba modernă, franceza veche și, mai cu seamă, franceza medie dispun de o întreagă serie de turnuri perifrastice de exprimare a [prospectivului], puternic marcate aspectual și care, inserate în diferite combinații de structuri frastice (atît paratactice, cît și hipotactice), exclud procesul din actualitate și îi conferă chiar o ușoară nuanță modală, virtuală, adesea retrospectivă.

De exemplu, devoir, cuidier sau vouloir urmate de infinitivul verbului lexical formează perifraze (des întîlnite în textele din Evul Mediu) care redau cumulativ un eveniment prospectiv marcat adesea și de următoarele seme: [+iminență $]+[+$ eșec $]$.

(4) Et quant ilz s'en furent allez, le roy cuydoit dormir, mais il nepouvoit, si veilla toute la nuyt (Jehan, 22, 1, 26, apud Martin, 1971, p. 174)

«Et quand ils s'en furent allés, le roi aurait voulu s'endormir, mais il n'aurait pas pu si (...)».

(5) Vespres aproche, li solaus dut cliner (Ami et Amile, 579, apud Ménard, 1976, p. 133). «Le soir vint, le soleil allait se coucher .

(6) Navrés estoit d'un roit espieu burni // Chaoir voloit ${ }^{2}$ del destrier arabi, // Quant. I. borgois en bras le saisi (Raoul de Cambrai, 3528, apud Buridant, 2000, p. 335).

«Blessé par une lance rigide bien fourbie, il allait tomber du cheval arabe quand un bourgeois le prit entre ses bras».

Aceeași interpretare o primesc și enunțurile, mult mai expresive, construite cu perifraza formată din participiul prezent (forma în -ant) — care indică un proces aflat pe cale să se realizeze-și verbul ester (adesea conjugat la indicativ viitor) [cf. limba română - v. Popescu, 2017]:

(7) Ja Loeys ne lor sera aidans (Raoul de Cambrai, 3929, apud Ménard, 1976, p. 171). «Louis ne leur viendra pas en aide».

(8) Ultre cest jurn ne serum plus vivant (Roland, 1520, apud Ménard, 1976, p. 171) «Au-delà de ce jour nous ne serons plus en vie».

Revenind însă la turnura aller + infinitiv, trebuie spus că aceasta începe să fie frecvent întîlnită în texte abia din secolul al XV-lea. La fel ca forma sintetică de V, cea analitică se înregistrează atît cu valori temporale cu sau fără raportare la $S_{i t}$ [v. ex. (9) și (10)], cît și cu valori temporalo-modale, frecvent deontice.

(9) Lors embrasse cellui qui lui rapporte // Et va passer trois fois devant la porte // Pour veoir la preuve, [...] (Chartier, Le débat des deux fortunes d'amour, 163, apud Lindschouw, 2011, p. 75) [V perifrastic utilizat într-un text datînd din anul 1412, cu valoare temporală generică, fără legătură $\mathrm{cuSit} \mathrm{S}_{0}$.

(10) SATHAN : Alons, Belzebuth, mauldit dyable, // Et portarons l'arme en enfer, BelzeButh : Mes griffes sont toutes de fer // De quoi je la vays accrocher (Anonyme, La passion d'Auvergne, 112, apud Lindschouw, 2011, p. 75) [V perifrastic utilizat într-un text datînd din anul 1477, cu valoare temporală dependentă de contextul situaţional descris de $\left.\mathrm{Sit}_{0}\right]$.

Totuși, din punctul de vedere al repartizării ocurențelor celor două paradigme în secolul al XV-lea, situația se prezintă astfel (apud Lindschouw, 2011, p. 73): în mai mult de jumătate din ocurențe (aprox. 89,5\%), forma canonică este utilizată cu valoare pur temporală, în 7,5\% din cazuri apare cu valoare temporalomodală, doar $2 \%$ din ansamblul utilizărilor reprezentînd ocurențe cu valoare modală pură. În schimb, forma analitică, aller + infinitiv, se întîlnește aproape în procent majoritar, de 99,5\%, în ocurențe cu valoare

\footnotetext{
${ }^{2}$ Această utilizare a dispărut din franceza literară încă din secolul al XVI-lea. Totuși, perifraza vouloir + infinitiv apare utilizată în diferite graiuri ale limbii franceze, echivalînd unui V indicativ (v. Ménard, 1976, p. 133).
} 
temporală, un număr infim, de $0,5 \%$ fiind afectat de o ușoară nuanță modală. Ceea ce este însă interesant, raportat la valoarea fundamentală pe care această structură o deține în limba actuală, este faptul că, în rîndul ocurențelor temporale, perifraza aller + infinitiv apare frecvent, nu cu raportare directă la $\mathrm{Sit}_{0}$ [ca supra sub (10)], ci cu valoare temporală generică, aşa cum s-a văzut anterior sub (9). Aceasta înseamnă-în statistica oferită de Lindschouw (2011, p. 72)—un raport de 1 (adică, 2\%) la 5 (adică, 10,5\%). Trebuie însă subliniat că din totalul ocurențelor temporale pe care perifraza în discuție le vehiculează în textele din secolul al XV-lea, cel mai mare număr este-și acesta este din nou un alt fapt surprinzător! —cel realizat în contexte narative istorice, unde însumează un procent de 82,5\% [v. ex. (11)], din totalul de 99,5\%:

(11) Quant vint le dimanche à matin et jour qu'il trespassa, fist appeler devant lui tous ses barons, prelay, son conseil et chancelier; adonc va parler devant eulz moult piteuses paroles, si que tous les contreigni à lermes (Ch. de Pizan, Le livre des fais et bonnes meurs du sage roy Charles V, 185, 2255, anul 1404, apud Lindschouw, 2011, p. 75).

(12) Sur ces propos, feirent leur accord, et, en regardant le lieu le plus propre pour faire ceste belle ceuvre, elle vat dire quelle n'en sçavoit poinct de meilleure ne plus loing de tout soupson, que une petite maison qui estoit dedans le parc, où il y avoit chambre et lict tout à propos. Le gentil homme, qui n'eust trouvé nul lieu mauvais, se contenta de cestuy-là (M. de Navarre, L'Heptaméron, 1550, apud Bres \& Labeau, 2013, p. 296).

Acest tip de utilizări ale perifrazei itive merită o discuție lărgită, atîta vreme cît ele au reapărut, se pare (v. Lindschouw, 2011, p. 76; Bres \& Labeau, 2013), și în limba franceză contemporană [v. infra, ex. (13)]:

(13) C'est le producteur Rob Fusari qui va trouver le nom de Lady Gaga, en s'inspirant de Radio Gaga, une chanson du groupe Queen. Dans cette logique, la créature Lady Gaga claque la porte du rock pour ouvrir celle de la dance musique, dans le sillage de Madonna. Avant de réussir à vendre 14 millions d'albums et 35 millions de singles en pleine crise du disque, Lady Gaga a puisé son inspiration dans le monde de la nuit new-yorkaise en se produisant avec DJ Lady Starlight qui va l'orienter vers l'exubérance esthétique. Dés lors, Lady Gaga va pousser la culture gay à son paroxysme ... (Le Monde, 16-17 mai 2010, apud Bres \& Labeau, 2013, p. 296).

Atestate sporadic încă din secolul al XII-lea (primele utilizări sînt semnalate în Orson de Beauvais și, ulterior, în sec. al XIII-lea, în Le Roman de la Rose), astfel de ocurențe sînt considerate a-și avea obîrșia în vechea gasconă (v. Lindschouw, 2011, p. 76), cu toate că structuri asemănătoare au fost înregistrate și în vechea occitană, în vechea castiliană sau în vechea portugheză (v. Bres \& Labeau, 2013, p. 299), iar în catalana actuală, turnura echivalentă, vaig cantar, s-a gramaticalizat ca o formă neutră de actualizare a [trecutului]. Acest tip de utilizare istorico-narativă a perifrazei aller + infinitiv se va diminua începînd din secolul al XVI-lea și va dispărea în secolul al XVIII-lea, pentru ca să reapară—după cum arată anumiți lingviști francezi (v., printre alții, Bres \& Labeau, 2013, p. 295-322) -în franceza contemporană. Bres \& Labeau (2013), care descriu astfel mecanismele generale de funcționare ale perifrazei discutate în contexte narative:

„[... the aller auxiliary in the present signifies a prospective orientation towards the initial boundary of the event expressed by the following infinitive that is ASPECTUALLY understood as having reached its final boundary. At a TEXTUAL level, that process introduces a new reference point in the diegesis and contributes to the progression of the narration. At a CONTEXTUAL level, i.e. at the level of linguistic context, it refers to an event located before the moment of narration-that is to say in the past. It works ANAPHORICALLY and not deictically: the prospective movement originates in the situation that precedes it rather than in the moment of speech" (Bres \& Labeau, 2013, p. 297), 
atrag atenția că între ocurențele vechi și cele contemporane există totuși o diferență importantă. Întradevăr, și într-o perioadă și în cealaltă, perifraza în discuție cu valoare de preterit poate fi înlocuită de o formă de prezent indicativ—ceea ce nu se poate întîmpla atunci cînd are valoare de V—şi nu acceptă niciodată intercalarea adverbului modalizator probablement „probabil”, cu care este însă compatibilă atunci cînd exprimă [prospectivul] generic sau raportat la $S_{i}{ }_{0}$. Diferența dintre utilizarea existentă în franceza medie și tiparul discursiv actual constă în posibilitatea de dependență şi/sau de coordonare contextuală față de un prezent indicativ (sau chiar față de o altă formă de V), situație valabilă doar pentru stadiul contemporan de funcționare. Luarea în calcul a acestui factor distinctiv îi determină pe Bres \& Labeau (2013) să considere că, de fapt, vechea turnură a încetat într-adevăr să mai existe în secolul al XVIII-lea, iar ocurențele echivalente din contemporaneitate reprezintă structuri discursive noi (reapărute timid încă din secolul al XVII-lea) și determinate de atributele prospective ale acestei perifraze itive. Spre deosebire de uzajul Evului Mediu, frecvent în textele narative sau academice scrise, utilizarea modernă se înregistrează foarte rar în scris, cu precădere în proza narativă de ficțiune, dar și în narațiunea interactivă din codul oral. Ocurențele moderne sînt însă mai numeroase în discursul mediatic sau în cel științific (v. Bres \& Labeau, 2013, p. 319). Apariția acestei noi utilizări a structurii prospective aller + infinitiv în franceza contemporană se poate explica astfel:

„En effet, sur la base de son interprétation future, $v a+$ INF. permet l'organisation de la narration, annonçant les faits suivants par un procès hyperonymique. La périphrase s’approche ainsi d'une valeur narrative en projetant le temps des événements sur celui de la narration. Avec la disparition de tous les marqueurs déictiques, les périphrases en aller cessent d'agir comme hypéronymes : elles apparaissent sur la même ligne temporelle que les situations voisines et s'interprètent comme actualisant des procès complètement réalisés » (Bres \& Labeau, 2013, p. 321).

Fără a continua detaliat o discuție în acest sens, trebuie să subliniem conclusiv pentru demersul nostru că acest tip de uzaj narativ al structurii itive aller + infinitiv (privit global—din Moyen Français și pînă în contemporaneitate) dovedește încă o dată că:

(i) în astfel de ocurențe (narative), morfemele verbale prospective implicate (fie că este vorba de V canonic sau chiar de anumite perifraze) nu sînt complet sinonime cu formele de trecut cu care pot fi înlocuite, ci funcționează ca marcatori (de diferite grade) de forță ilocuționară. Acesta este probabil şi motivul pentru care Wilmet (1970, p. 188) consideră acest uzaj de actualizare a viitorului în trecut ca fiind unul ,impur”;

(ii) privită din perspectiva teoriei clasice și extinse a gramaticalizării, parcursul diacronic al turnurii aller + infinitiv arată că (1) aceeași structură se poate gramaticaliza diferit și chiar diametral opus de la un sistem lingvistic la altul (cf. situația din catalană), respectiv, că (2) același item deja gramaticalizat poate dezvolta semnificații discursive similare în diferite perioade de „viaţă” datorită existenței unei trăsături semice fundamentale/bazice în sememul său.

Revenind la discuția generală referitoare la procesul de regramatizare a V canonic, reamintim faptul că epoca dispariției ocurențelor narative ale structurii aller + infinitiv din limba franceză coincide grosso modo cu specializarea $\mathrm{V}$ canonic în actualizarea [prospectivului] detașat de universul alocentric, adică ca morfem temporal prospectiv care focalizează mai degrabă acțiunea/evenimentul exprimat(ă) de verb (de fapt, momentul evenimentului) și mai puțin situația de comunicare. La polul opus, trebuie subliniat și faptul că, prin pierderea numărului mare de ocurențe narative, forma analitică de V și-a consolidat:

„[...] son statut comme forme temporelle 'authentique', de par sa capacité à marquer un rapport avec le moment de l'énonciation, cette valeur étant passée de $2,0 \%$ au $15^{\mathrm{e}}$ siècle à $90,5 \%$ au $18^{\mathrm{e}}$ siècle. Ce contenu s'observe dans un vaste éventail de genres textuels (c.-à-d. textes argumentatifs et littéraires, discours direct et pièces de théâtre en vers et en prose), ce qui peut être interprété comme un témoignage du fait qu'il appartient à toute la réalité langagière" (Lindschouw, 2011, p. 83). 
În acest context, trebuie totuși reiterată ideea conform căreia acestă varietate discursivă și acest număr mare de ocurențe ale structurii perifrastice apar mai cu seamă în codul scris unde se remarcă însă și asocierea acestui morfem verbal mai degrabă cu actualizarea unei acțiuni viitoare generice, deci neraportată la $\mathrm{Sit}_{0}$. Toată această panoramă descriptivă arată de fapt că forma analitică de V și-a lărgit domeniul de utilizare: chiar dacă valoarea originară, aceea de exprimare a unei acțiuni prospective raportată la $S_{i t}$ (deci, actualizarea unui V imediat/apropiat) a scăzut ca număr de ocurențe, ea se păstrează totuși, mai cu seamă în limba scrisă. Pe lîngă această valoare, aller + infinitiv s-a extins, cu precădere în codul oral, în zona de funcționare altădată rezervată exclusiv formei sintetice, anume aceea de actualizare a unui V generic, neraportat la $\mathrm{Sit}_{0}$.

„Toutefois, il serait faux d’affirmer que ce tiroir verbal [le futur] a subi un processus de désemantisation, puisque, en dépit des réductions qu'il a connues, il constitue toujours un système temporel bipartite quoique dans une moindre mesure quà l'origine. Il n'a pas subi un processus d'obligatorification' ou de spécialisation de son emploi, et par là une réduction paradigmatique" (Lindschouw, 2011, p. 89).

Cu toate acestea, ar fi prematur să spunem că forma canonică de V din limba franceză a parcurs și a finalizat procesul de regramatizare, pentru că cele două paradigme verbale pot comuta încă în anumite contexte (cf. infra, ex. (14a) și (14b); pentru mai multe detalii, v. Costăchescu, 2013, p. 167-172):
a. Jean se mariera l'an prochain.
b. Jean va se marier l'an prochain (apud Helland, 1995, p. 5).

\subsection{Forma în -rai vs. perifraza modală devoir + infinitiv}

În ceea ce privește utilizările cu valoare modală ale formei canonice de V-valoare care am văzut că nu s-a dezvoltat din uzajul temporal, ci a coexistat cu acesta încă din epoca veche a limbii franceze-, în limba actuală, numărul ocurențelor de acest tip este unul mic, comparativ cu alte sisteme romanice (de ex., italiană sau română), însă mai ridicat față de alte stadii de evoluție. Pentru ca această aserțiune să fie validă, trebuie făcută o disociere a tipurilor de utilizări modale ale V, în utilizări epistemice și alte tipuri de utilizări, în speță cele atenuative și deontice. În acest cadru metodologic, trebuie precizat că în Ancien și Moyen Français, numărul ocurențelor atenuative și iusive este într-adevăr unul ridicat, spre deosebire de cel al utilizărilor epistemice care sînt rare și rezervate—cum am văzut mai sus—doar turnurilor interogativo-exclamative unde valoarea de [probabilitate dubitativă] este degajată nu de morfemul verbal de V, ci de întreaga structură enunțiativă. Se remarcă totuşi faptul că în această epocă, V din astfel de turnuri epistemice se combină cu o gamă mult mai largă și mai variată de verbe față de situația din franceza contemporană (unde apare restrîns la être și avoir) și are un comportament sintactico-semantic similar cu cel al condiţionalului prezent [cf. (15a) și (15b)]:

a. - Regardez quel fut vostre entraige

- Auront prins fin tous mes plaisirs? (E. Picot, Recueil général des sotties, apud Squartini, 2004, p. 88).

b. Seroient toutes mes marchandises / Par ung seul cas ainsi surprises? (E. Picot, Recueil général des sotties, apud Squartini, 2004, p. 88).

Așadar, doar privite în ansamblu, toate aceste ocurențe ale V (numite grosso modo „modale”: deontice, atenuative și epistemice) pot fi considerate majoritare în limba actuală și acest lucru se referă, mai cu seamă, la limba scrisă.

În limba vorbită însă, $\mathrm{V}$ atenuativ este frecvent înlocuit de condițional, iar $\mathrm{V}$ epistemic fie apare în distribuție complementară (în funcție de tipul de frază) cu forma în -roie, fie este înlocuit de perifraza 
modală devoir ${ }_{\text {Еріsтеміс }}+$ infinitiv, o turnură care reprezintă forma de expresie favorită (v. Wales, 2007; Gobert \& Maisier, 1995, p. 1003-1014) pentru actualizarea [probabilităţii epistemice] cu raportare la [prezent-viitor], dar și la [trecut].

Această din urmă perifrază, devoir + infinitiv—atestată cu valoare epistemică destul de devreme, aprox. în anul 1100-, nu reprezintă o moștenire din latină, deoarece DEBERE avea acolo doar semnificaţia de „obligație” sau de „necesitate”. Semnificația epistemică [v. ex. (17)] este ulterioară acestor stadii și ea este cunoscută și de forma echivalentă din italiană.

(16) Li soens orgoilz le devreit bien confondre (La chanson de Roland, versul 389, apud TLF, citat de Rossari et al., 2007, p. 11).

(17) Mais ildoit moltcels anuier // Quiperdue l'ont folement (Vair Parlefroi, 1254, apud Ménard, 1976, p. 134).

«Mais ceux qui l'ont sottement laissée partir doivent sans doute être fort ennuyés».

În literatura de specialitate, există două poziții în legătură cu gramaticalizarea urmașilor lui DEBERE ca mărci ale modalității epistemice: fie valoarea epistemică derivă din cea deontică, de „obligație”, așa cum susţin Bybee et al. (1994), fie este vorba de o trecere de la aletic la epistemic, aşa cum propune Kronning (1990, p. 301-312) (v. și Bourova, 2005, p. 310-312). În orice caz, numărul ocurențelor modale cu valoare de „obligație” sau de „necesitate” este net superior în raport cu cel al utilizărilor epistemice în Ancien și Moyen Français, comparativ cu situația existentă în contemporaneitate, unde-observă Rossari et al. (2007, p. 11) - proporţia se inversează. Această statistică demonstrează în primul rînd faptul că lectura epistemică degajată de această structură perifrastică este cu siguranță posterioară celei de „obligație” sau de „necesitate”.

\section{Cîteva concluzii}

În ceea ce privește evoluția formei canonice de V din limba franceză, este cert faptul că această paradigmă verbală se găsește în plin proces de regramatizare, căci:

- la nivelul ocurențelor temporale, concurența cu perifraza itivă (gramaticalizată) aller + infinitiv determină nu numai o scădere a frecvenței de utilizare, mai cu seamă, în limba vorbită, ci și o reconfigurare a celor două paradigme în raport cu referirea la $\mathrm{Sit}_{0}$. Forma sintetică continuă să actualizeze [prospectivul] generic, dar pierde și aici din numărul utilizărilor, în timp ce structura analitică cîștigă teren în marcarea unui V fără raportare la Sit $t_{0}$, fără să își piardă însă nici valoarea sa bazică de marcare a unui [viitor] imediat/apropiat. O consecință imediată a încercării de desprindere de raportarea la situația de comunicare și de marcare generică a referinței temporale prospective este utilizarea posibilă (cu precădere în codul oral) a acestei turnuri perifrastice în contexte epistemico-evidențiale, de tipul:

(18) On a sonné à la porte. Ça va encore être les témoins de Jéhovah.

- la nivelul ocurențelor modale epistemice, V sintetic nu mai apare în structuri dubitativo-interogative ca în Moyen Français și se combină doar cu être și avoir și cu tipul de frază asertiv, dînd naștere, de fapt, unor turnuri aproape fixe de marcare a [probablităţii epistemice]. În acest sector cognitiv, V sintetic este puternic concurat de perifraza modală (încă incomplet gramaticalizată) devoir еріsтеміс $_{\text {infinitiv }}$ și de formele de condițional. Distribuția complementară cu acest din urmă morfem verbal arată faptul că limba franceză operează o dezambiguizare între două zone cognitivo-enunțiative, anume [dubitativul] și [inferențialul]. Pe de altă parte, concurența funcțională—din ce în ce mai marcată, în special în codul oral一, cu perifraza modală demonstrează nu numai o scădere a numărului de ocurențe de acest tip ale $\mathrm{V}$ sintetic, ci chiar o regramatizare completă a sa în această zonă de expresie: V sintetic devine per se un marcator de inferență inductivă, care nu mai marchează relația de dependență (logică, contextuală, argumentativă și enunțiativă) cu ansamblul referențial $R$ (v. Popescu, 2016), ci pare să 
îl conțină intrinsec (altfel spus, l-a asimilat, l-a gramaticalizat). Toată această ipoteză repoziționată din perspectiva [evidențialității], ne determină să reconsiderăm, așa cum arată și Rossari et al. (2007), opoziția existentă în franceza contemporană între $V$ sintetic și perifraza modalizată pe baza dihotomiei [ \pm indicare a sursei de obținere a informației], $V$ sintetic fiind forma nemarcată din acest punct de

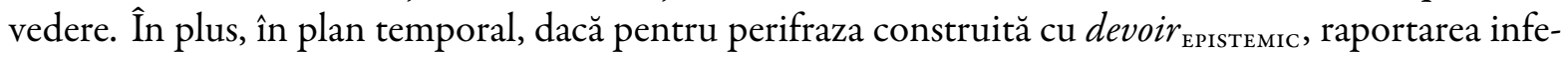
renței se poate configura din punctul de vedere al dihotomiei [trecut] - [non-trecut], în cazul formei sintetice de V, această raportare se realizează doar în parametrii [prezent-viitor] - (rar) [viitor].

- restrîngerea ariei globale de utilizare a formei sintetice de $\mathrm{V}$ se observă și la nivelul celorlalte tipuri de ocurențe (cele temporalo-modale-iusive, deontice etc.—sau cele atenuative) care și ele se găsesc în regresie față de alte stadii de evoluție ale acestui sistem lingvistic (v. Popescu, 2013).

\section{Bibliografie}

Andersen, H. (ed.) (2001). Actualization: Linguistic Change in Progress, John Benjamins, Amsterdam / Philadelphia, Crossref. Andersen, H. (2006). Grammation, regrammation and degrammation: tense loss in Russian, în „Diachronica”, vol. 23, nr. 2, p. 231-258, Crossref.

Barcelo, G.J. (2007). Le(s) futur(s) dans les langues romanes: évolution linéaire ou cyclique?, în „Cahiers Chronos” [Labeau, E. (ed.). "Sémantique et diachronie du système verbal français"], vol. 16, p. 47-62.

Bourova, V. (2005). À la recherche du 'conditionnel latin': les constructions Infinitif + forme de HABERE examinées à partir d'un corpus électronique, în Kabatek, J., Pusch, C. D., Raible, W. (eds), Romanistische Korpuslinguistik II: Korpora und diachrone Sprachwissenschaft / Romance corpus linguistics II: corpora and diachronic linguistics, Gunter Narr, Tübingen, p. 303-315.

Bres, J. \& Labeau, E. (2013). The narrative construction va + INFINITIVE in Contemporary French, în „Diachronica”, vol. 30, nr. 3, p. 295-322, Crossref.

Buridant, C. (2000). Grammaire nouvelle de l'ancien français, SEDES, Paris.

Bybee, J., Perkins, W. \& Pagliuca, J.-R. (1994). The Evolution of Grammar. Tense, Aspect and Modality in the Languages of the World, The University of Chicago Press, Chicago / Londra.

Corcheș, C. \& Roman, D. (2011). Observations on the regenerative capacity of grammatical structures: the Romanian present presumptive, în Ciulei, T., Sandache, C. \& Sandu, A. (eds), Logos, Universalitate, Mentalitate, Educație, Noutate. Secţiunea Filosofie și Științe Umaniste / Logos Universality Mentality Education Novelty. Section: Philosophy and Humanistic Sciences, vol. 1, Editura Lumen, Iași, p. 309-324.

Costăchescu, A. (2013). La pragmatique linguistique : théories, débats, exemples, Lincom Europa, Berlin.

Fleischman, S. (1982). The future in thought and language. Diachronic Evidence from Romance, Cambridge University Press, Cambridge.

Gobert, D.L. \& Maisier, V. (1995). Valeurs modales du futur et du conditionnel et leurs emplois en français contemporain, în „The French Review", vol. 68, nr. 6, p. 1003-1014.

Harris, M. (1978). The Evolution of French Syntax. A comparative approach, Longman Group Ltd, Londra / New York.

Helland, H.P. (1995). Futur simple et futur périphrastique: du sens aux emplois, în „Revue Romane”, vol. 30, nr. 1, p. 3-26, [online].

Hopper, P.J. \& Closs-Traugott, E. (2003). Grammaticalization, Cambridge University Press, Cambridge.

Kronning, H. (1990). Modalité et diachronie: du déontique à l'épistémique. L'évolution sémantique de «debere/devoir», în „Actes du XIe Congrès des Romanistes Scandinaves", Trondheim, p. 301-312.

Lehmann, Ch. (1985). Grammaticalization: Synchronic Variation and Diachronic Change, în „Lingua e Stile”, vol. 20, nr. 3, p. 303-318.

Lindschouw, J. (2011). Lévolution du système du futur du moyen français au français moderne: la réorganisation comme un cas de régrammation, în „Revue de Linguistique Romane”, vol. 75, nr. 297-298, p. 51-98.

Lindschouw, J. (2013). Passé simple et passé composé dans l'histoire du français. Changement paradigmatique, réorganisation et régrammation, în „Revue de Linguistique Romane”, vol. 77, nr. 305-306, p. 87-120.

Martin, R. (1971). Temps et aspect. Essai sur l'emploi des temps narratifs en moyen français, Éditions Klincksieck, Paris.

Ménard, Ph. (1976). Manuel du français du Moyen Âge. 1. Syntaxe de l'ancien français, Editions Bière, Bordeaux.

Meillet, A. (1912). L'évolution des formes grammaticales, în Linguistique historique et linguistique générale, Honoré Champion, Paris, p. 130-148.

Moignet, G. (1959). Essai sur le mode subjonctifen latin postclassique et en ancien français, 2 vol., Presses Universitaires de France, Paris.

Moignet, G. (1976). Grammaire de l'ancien français. Morphologie-Syntaxe, Librairie Klincksieck, Paris.

Popescu, C.M. (2013). Viitorul și condiționalul în limbile romanice. Abordare morfosintactică și categorizare semantică din perspectivă diacronică, Editura Universitaria, Craiova. 
Popescu, C.M. (2016). Manifestations discursives du «futur épistemique » en français contemporain, în Guță, A., Popescu, M. \& Teodorescu, C. (coord.), Actes du colloque international « 50 ans de français a l'Universite de Craiova (1966-2026) », Craiova, du 19 au 20 mai 2016, vol. 1: Perspectives linguistiques et lexicographiques, Editura Universitaria, Craiova, p. 201218.

Popescu, C.M. (2017). Evoluția sistemului formelor prospective din limba română, un exemplu de regramatizare, în Stanciu Istrate, M. \& Răuțu, D. (eds), Lucrările celui de-al VI-lea Simpozion Internațional de lingvistică. Omagiu domnului academician Marius Sala, la aniversare, Editura Univers Enciclopedic Gold, București, p. 624-635.

Rossari, C., Cojocariu, C., Ricci, C. \& Spiridon, A. (2007). Devoir et l'évidentialité en français et en roumain, în „Discours. Revue de linguistique, psycholinguistique et informatique”, 1, Presses Universitaires de Caen, Caen, p. 2-15, [online].

Squartini, M. (2004). La relazione semantica tra futuro e condizionale nelle lingue romanze, în „Revue Romane”, vol. 39, nr. 1, p. 68-96, Crossref.

Wales, M.L. (2007). Modal Functions of Future Tenses in French, în Mushin, I. \& Laughren, M. (eds), Selected Papers from the 2006 Annual meeting of the Australian Linguistic Society, University of Queensland, Brisbane, p. 1-14, [online].

Wilmet, M. (1970). Le système de l'indicatif en Moyen Français, Droz, Geneva. 